\title{
Conservational significance of Dunumadalawa Forest Reserve in Central Sri Lanka based on the endemism of its avifauna
}

\author{
Tharangi Hettiarachchi ${ }^{1, *}$ and Chaminda S. Wijesundara ${ }^{1}$ \\ ${ }^{I}$ Department of Zoology, University of Peradeniya, Peradeniya, Sri Lanka
}

Received: 12/02/2017; Accepted: 15/08/2017

\begin{abstract}
The concept of endemism is useful in evaluating the biological significance and uniqueness of an area. It is a meaningful alternative to simple species richness and can be used as a relevant measure in assessing conservational significance. Dunumadalawa $\left(7^{\circ} 17^{\prime} 00^{\prime \prime} \mathrm{N}\right.$; 80³8'49"E; 548-972 m above sea level) is a semi-isolated, hill country wetzone forest reserve located in Kandy District, Sri Lanka. It is approximately 480 ha in extent, and comprises mainly of secondary growth forest. The objective of the present study was to determine the level of endemism of its avifauna to justify its conservational significance. The study was carried out from January to September, 2015. A line transect integrated with a point count method was used to collect data. Peak sampling hours were between 0600$0900 \mathrm{~h}$ and $1500-1800 \mathrm{~h}$ in sites selected by systematic random sampling. Density estimation was done using Distance ${ }^{\circledR}$ software. As a control, results were compared with those of nearby home gardens. According to Shannon $\left(H^{\prime}\right)$ and Simpson (1-D) Diversity Indices avifaunal diversity in Dunumadalawa was comparatively higher $\left(H^{\prime}=3.56\right.$, $(1-D)=0.959)$ than that of the home gardens $\left(H^{\prime}=\right.$ 2.98, $(1-D)=0.923)$. Dunumadalawa harbours 13 out of 33 endemic bird species in Sri Lanka (39.4\%) and 29 endemic subspecies out of $68(42.7 \%)$. The forest is also refuge for 10 of the $23(43.5 \%)$ restricted range bird species. Due to the presence of endemics and restricted range species, Dunumadalawa, which serves as a habitat island in the midst of a large urban area, merits special conservation attention.
\end{abstract}

Keywords: Endemic birds, Diversity, Threats, Conservation, Dunumadalawa Forest.

\section{INTRODUCTION}

Sri Lanka is a tropical island located at the southernmost tip of South Asia $\left(5^{\circ} .55^{\prime}-9^{\circ} .55^{\prime} \mathrm{N}\right.$, $\left.79^{\circ} .42^{\prime}-81^{\circ} .52 ' \mathrm{E}\right)$. The climate of Sri Lanka is tropical with two distinct dry and wet seasons. The distinct geographical features of Sri Lanka have given rise to three major climatic zones, viz. wet, dry and intermediate zones. These climatic conditions together with unique topographies create a wide variety of habitats supporting a high avifaunal diversity (Warakagoda and Sirivardana, 2009). Hence, Sri Lanka has one of the highest bird species richness in Asia (Kotagama and Wijayasingha, 1998).

The avifauna of the island consists of 454 species at present (Warakagoda et al., 2012). This includes 238 species of birds known to breed in Sri Lanka, including 33 species and 68 subspecies that are currently recognised as endemic (Warakagoda and Sirivardana, 2009). Moreover, Sri Lanka also has 23 bird species categorised as restricted ranged species and it exceeds more than any other endemic bird area in this region (BirdLife International, 2017). Sri Lanka has been declared as an Endemic Bird Area (EBA 124) by the BirdLife International (Chan et al., 2004) which encompasses the over lapping breeding ranges of restricted range species. Endemic species are the species that are confined to a particular geographical area. In Sri Lanka, majority of the endemic bird species are restricted to the low-country wet zone forests and hill country primary montane forests (Wijesundara and de Silva, 2005).

Dunumadalawa Forest Reserve $\left(7^{\circ} 17^{\prime} 00^{\prime \prime} \mathrm{N} ; 80^{\circ} 38^{\prime} 49^{\prime \prime} \mathrm{E}, 548-972 \mathrm{~m}\right.$ above sea level; also known as Walker Estate or 'Waraka Wattha'), is a semi isolated, mid-country wet zone forest fragment situated in the Kandy District. It is approximately 480 ha in extent and is located within the municipal limits of the Kandy City. Dunumadalawa comprises mainly of secondary growth forest since the site has been used earlier for tea and cocoa plantations. At present, few primary forest patches are remaining in the forest reserve. This historical forest reserve forms the catchment and protects the watershed of two reservoirs known as Dunumadala Wewa and Roseneath Wewa which augment the water 
supply to the Kandy City (Dharmasena et al., 2001).

The forest consists of different types of habitats such as woody areas, grasslands, pine plantations, and several permanent and temporary lentic and lotic water bodies. It is also characterized by canopy and sub-canopy of mixed plant species which include native species. In addition, there are some Jackfruit (Artocarpus heterophyllus) and Mango (Mangifera indica) trees which are remnants from the previous landuse types. The understory is occupied by unmanaged tea, coffee and cocoa in some areas and is dominated by invasive plant species such as Yakada maran (Myroxylon balsamum) throughout the other areas. Grassland patches found within the forest are comprised mostly of Cogon Grass (Imperata cylindrica). The forest also includes a Caribbean Pine (Pinus caribaea) plantation at its highest point in the southeast. Apart from living plants, the forest has a number of tree snags scattered across the area. Except the invasive plant species, the composition of other plant species and the associated habitats together with micro-climatic parameters support a high diversity of fauna despite its small size. Since the forest is enclosed by municipal areas with human settlements, it necessarily forms a habitat island in the middle of a swarming city.

Patterns of species abundance and coexistence are commonly determined by habitat quality including competition for food, availability of breeding sites and the predator pressure (Jones et al., 2014). Similarly there are many important factors associated with the occurrence and abundance of avian species that probably act outside the breeding season. The species composition of the vegetation and frequency of the occurrence of major tree species play major roles in habitat selection by birds (Rice et al., 1983). Conversely, MacArthur and MacArthur (1961) determined that structural diversity of the habitat show overrding influence than the plant species composition. Therefore, both plant species composition and foliage structure have an impact on the distribution of bird species in a particular habitat by producing more food varieties hence supporting a more diverse bird community (MacArthur and MacArthur, 1961; Carey et al., 1999). In addition, the edge effect also has a substantial effect on the bird species composition (Murcia,
1995). However, when considering a forest fragment which functions as a green space in the middle of a city, all above features play a significant role in determining the avifaunal stock it harbours. Additionally, isolation and stability are the two main factors that influence the degree of endemism.

Dunumadalawa forest is vital for the survival of a diverse avifauna. However, according to available literature, no previous studies have been carried out to evaluate the diversity of birds in this forest. Therefore, the overall objective of the present study was to document the endemism shown by the bird fauna of the Dunumadalawa Forest Reserve with the aim of highlighting the biological uniqueness of the forest patch to generate an awareness to conduct a proper conservational assessment on its avifauna.

\section{MATERIALS AND METHODS}

\section{Study Sites}

The present study was carried out in two sites for the comparison. The first site was the Dunumadalawa Forest Reserve, Kandy $\left(7^{\circ} 17^{\prime} 00^{\prime \prime}\right.$ N, 80³8'49" E; 548-972 m above sea level) (

Figure 1). This forest reserve has a total area of 480 ha and is mainly a secondary growth midelevation wet zone forest patch bordered by tea estates, urban areas, and villages. The second site was the home gardens that are located within 50 $\mathrm{m}$ north-eastwards from the Dunumadalawa

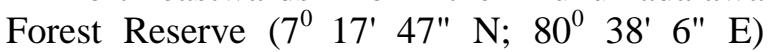
(Figure 2).

\section{Field sampling}

The study was conducted from January to September, 2015. The study sites were visited twice a month. Data were collected using line transects integrated with point counts (Bibby et al., 1998; Bibby et al., 2000; Sutherland, 2006). Peak observation hours were between 0600-0900 $\mathrm{h}$ and 1500-1800 $\mathrm{h}$. Two night sampling sessions were carried out to evaluate the nocturnal bird diversity. Line transects were selected mainly according to the existing network of footpaths lies through the forest. Sampling sites (points) were assigned using a Magellan Global Positioning System (GPS) and stations were separated by a minimum distance of $200 \mathrm{~m}$ (approximately 340 paces) in order to ensure 
statistical independence of point counts and to avoid double counting as much as possible (Ralph et al., 1995). The starting point for sampling was randomly selected and then preceded in a randomly determined direction spending 15 to 20 minutes at each point. For night sampling, bird calls were recorded. The observations were not carried out during extreme weather conditions such as heavy rain (Bibby et al., 2000). As a control experiment, the same sampling protocol was used and same sampling effort was done in nearby home gardens and results were compared with those of the forest reserve.

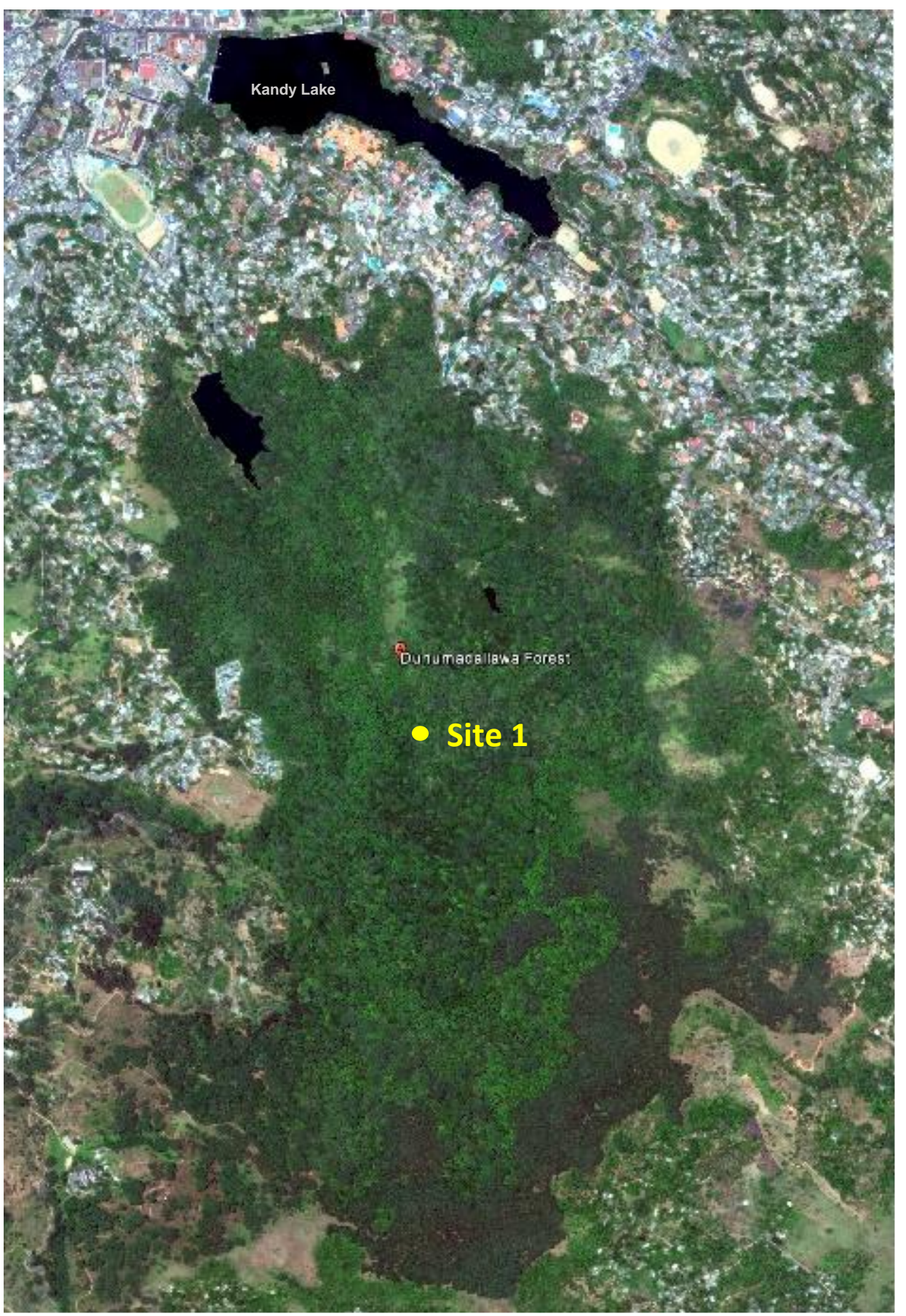

Figure 1 Site 1: Satellite image of the Dunumadalawa Forest Reserve, Kandy ( $7^{\circ} 17^{\prime} 00^{\prime \prime}$ North, $80^{\circ} 38^{\prime} 49^{\prime \prime}$ East; $548-960 \mathrm{~m}$ above sea level). (Source: Google Maps, Google, Inc., 2015). 


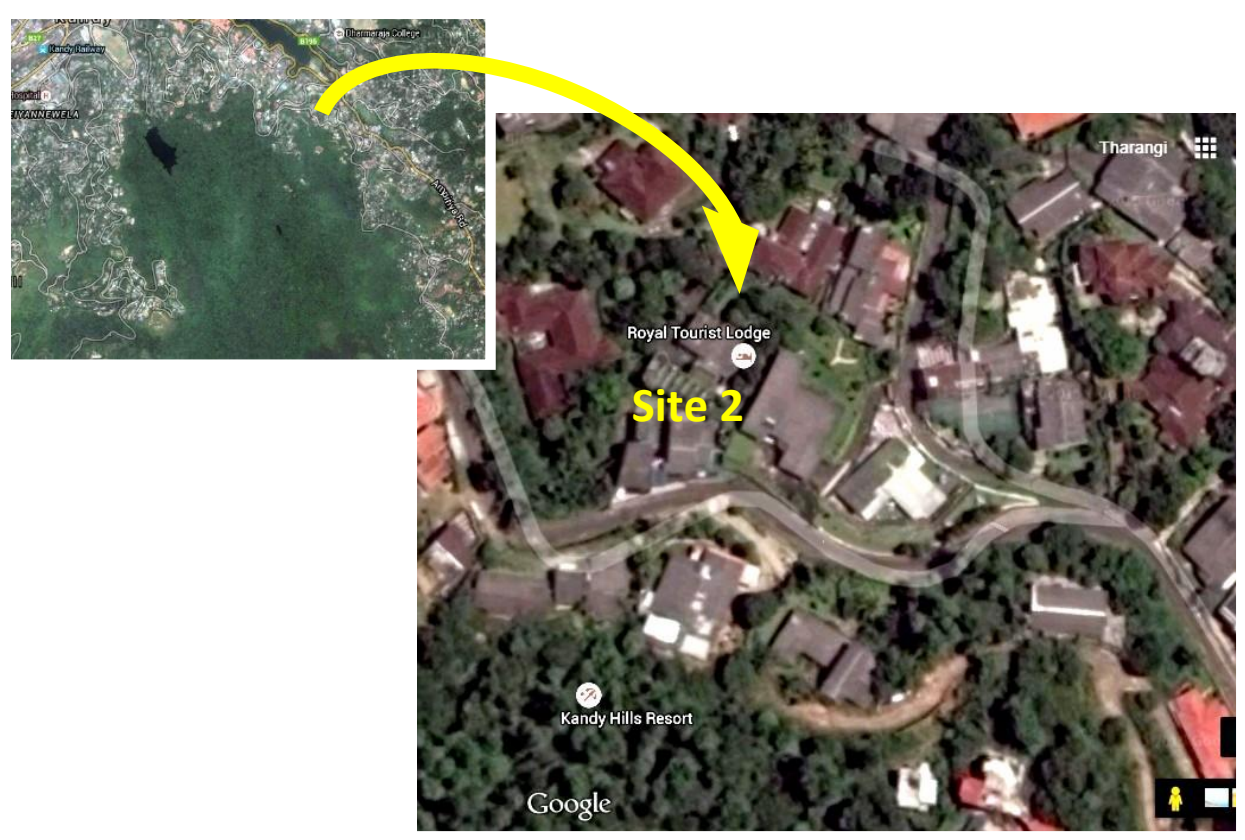

Figure 2: Site 2: Home gardens adjacent (within $50 \mathrm{~m}$ ) to the north-eastwards side of the margin of Dunumadalawa Forest Reserve ( $7^{\circ} 17^{\prime} 47^{\prime \prime}$ North, $80^{\circ} 38^{\prime} 6^{\prime \prime}$ East) (Along the Rajapihilla Mawatha). (Source: Google Maps, Google, Inc., 2015).

\section{Distance sampling}

Distance estimation was done wherever possible by estimating the radial distance (actual distance or ' $r$ ') from the counting point to the bird using a Bushnell Yardage Pro Compact 800 range finder. For all other contacts, the radial distance was estimated to the nearest meter (Wijesundara and Wijesundara, 2014). For a group of birds, the geometric centre was considered to estimate the distance (Ralph and Scott, 1981; Wijesundara and de Silva, 2005). If any birds were disturbed (flushed) while approaching a counting station, they were recorded as being present, and the distance from the counting point to the bird's take-off point was estimated. Before starting sampling, around two minutes were spent after reaching a particular point to allow the birds to settle if any disturbance has been made by the approach.

\section{Species identification}

Standard birding binoculars (Nikon $8 \times 42$ ) were used for direct visual identification of birds.Their calls were recorded as an indirect method of further identification. All individual birds seen and heard and their abundance at each point were recorded. Birds were identified up to the species level using field guides (Harrison, 2011; Warakagoda et al., 2012) and recorded calls were compared with the standard MP3 sound recordings (Warakagoda, 2007). Furthermore, species accumulation curves were drawn to check the adequacy of the sampling effort (Hortal et al., 2006) (Figure 3).

\section{Data analysis}

Species richness (S) was calculated as a simplest measure of diversity. EstimateS version 9 Software (Colwell, 2013) was used to calculate the Shannon $\left(H^{\prime}\right)$ and Simpson (1-D) diversity indices for the avifauna in both sites. Jaccard's index was calculated to compare the similarity of avifaunal richness between the two sites.

The abundance values together with the sampling effort were treated with a two sample $t$ test using Minitab software (Minitab, 2010) to determine any significant differences between the two sites. Estimation of density for commonly encountered species was obtained using Distance software (Thomas et al., 2010). Further analyses were done using the raw data on species composition and abundance. 


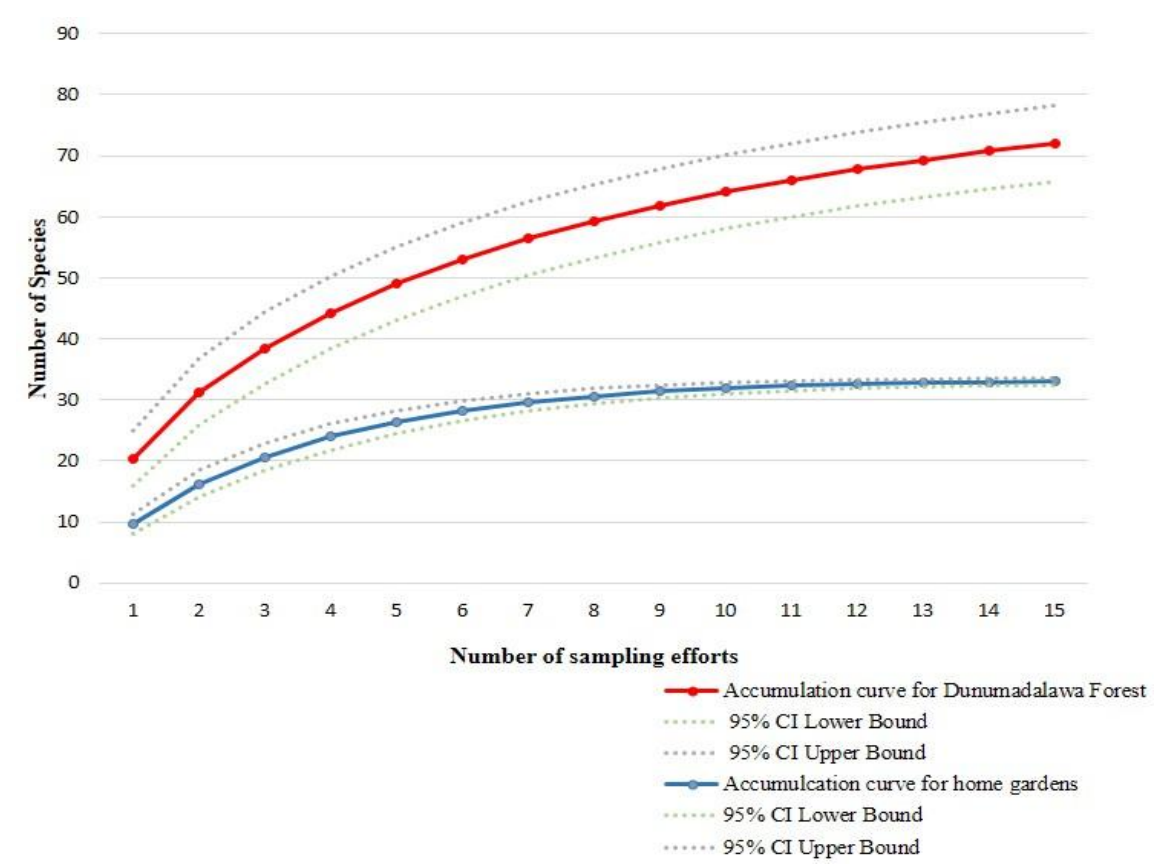

Figure 3: Species accumulation curves drawn to check the adequacy of sampling.

Table 1: Endemism shown by the bird species and restricted range bird species in the two sites compared to the avifauna of Sri Lanka.

\begin{tabular}{llll}
\hline & $\begin{array}{l}\text { No of Endemic } \\
\text { Species }\end{array}$ & $\begin{array}{l}\text { No of Restricted Range } \\
\text { Species }\end{array}$ & $\begin{array}{l}\text { No of Endemic } \\
\text { Subspecies }\end{array}$ \\
\hline Sri Lanka & 33 & 27 & 68 \\
\hline Dunumadalawa Forest & $12(36.4 \%)$ & $9(33.3 \%)$ & $27(40.9 \%)$ \\
\hline Nearby home gardens & 5 & 5 & 8 \\
\hline
\end{tabular}

Table 2: Endemic bird species identified in Dunumadalawa Forest Reserve and their relative abundance (sorted by relative abundance).

\begin{tabular}{llcc}
\hline \multicolumn{1}{c}{$\begin{array}{c}\text { Bird species } \\
\text { Common name) }\end{array}$} & \multicolumn{1}{c}{ Scientific name } & $\begin{array}{c}\text { Restricted } \\
\text { range } \\
\text { species }\end{array}$ & $\begin{array}{c}\text { Relative } \\
\text { abundance } \\
(\%)\end{array}$ \\
\hline Yellow-fronted Barbet & Psilopogon flavifrons & + & 8.4 \\
\hline Sri Lanka Brown-capped Babbler & Pellorneum fuscocapillus & + & 4.5 \\
\hline Crimson-fronted Barbet & Psilopogon rubricapillus & + & 3.7 \\
\hline Sri Lanka Scimitar Babbler & Pomatorhinus melanurus & + & 1.8 \\
\hline Sri Lanka Wood-Pigeon & Columba torringtoniae & + & 0.9 \\
\hline Layard's Parakeet & Psittacula calthrapae & + & 0.6 \\
\hline Crimson-backed Flameback Woodpecker & Chrysocolaptes stricklandi & + & 0.5 \\
\hline Sri Lanka Junglefowl & Gallus lafayettii & + & 0.5 \\
\hline Sri Lanka Hanging-Parrot & Loriculus beryllinus & + & 0.3 \\
\hline Sri Lanka Gray Hornbill & Ocyceros gingalensis & 0.3 \\
\hline Black-capped Bulbul & Pycnonotus melanicterus & 0.3 \\
\hline Spot-winged Thrush & Zoothera spiloptera & + & 0.1 \\
\hline Sri Lanka Woodshrike & Tephrodornis affinis & & + \\
\hline
\end{tabular}




\section{RESULTS}

Our results suggest that the bird diversity in Dunumadalawa is significantly higher $\left[H^{\prime}=3.56\right.$, $(1-D)=0.959]$ than in nearby home gardens [ $\left.H^{\prime}=2.98,(1-D)=0.923\right]$. A $t$-test for $H^{\prime}$ revealed that the two sites are significantly different in terms of bird diversity $(p=<0.001 ; \mathrm{t}=4.09 ; \mathrm{df}=17)$ with a substantial level of endemism. Furthermore, according to Jaccard's index the forest reserve and home gardens has shown a $29.3 \%$ similarity in terms of species diversity.

The avifauna in Dunumadalawa Forest consists of 13 out of 33 endemic bird species in
Sri Lanka (39.4\%) and 29 endemic subspecies out of $68(42.7 \%)$. Including these, the forest hosts $10(43.5 \%)$ restricted range species. This makes up to $41.6 \%$ of total endemism (Table 1, Table 2 and Table 3). The Yellow-fronted Barbet (Psilopogon flavifrons), Brown-capped Babbler (Pellorneum fuscocapillus), Crimson-fronted Barbet (Psilopogon rubricapillus), Sri Lanka Scimitar Babbler (Pomatorhinus melanurus) and Sri Lanka Wood-Pigeon (Columba torringtoniae) were the most abundant endemic species recorded in the site (Table 2). However, the Yellow-fronted Barbet (Psilopogon flavifrons) has shown the highest density in Dunumadalawa Forest Reserve (Table 4).

Table 3: Endemic subspecies of birds recorded in Dunumadalawa Forest Reserve.

\begin{tabular}{|c|c|}
\hline Bird Species (Common Name) & Scientific Name \\
\hline Crested Serpent-Eagle & Spilornis cheela spilogaster \\
\hline Crested Hawk-Eagle & Nisaetus cirrhatus ceylanensis \\
\hline Emerald Dove & Chalcophaps indica robinsoni \\
\hline Jerdon's Nightjar & Caprimulgus atripennis aequabilis \\
\hline Brown Fish-Owl & Ketupa zeylonensis zeylonensis \\
\hline Brown Wood Owl & Strix leptogrammica ochrogenys \\
\hline Lesser yellownape Woodpecker & Picus chlorolophus wellsi \\
\hline Black-rumped Flameback Woodpecker & Dinopium benghalense psarodes \\
\hline Brown-capped Pygmy Woodpecker & Dendrocopos nanus gymnopthalmus \\
\hline Bar-winged Flycatcher-shrike & Hemipus picatus leggei \\
\hline Black-hooded Oriole & Oriolus xanthornus ceylonensis \\
\hline White-bellied Drongo & Dicrurus caerulescens leucopygialis \\
\hline Red-vented Bulbul & Pycnonotus cafer cafer \\
\hline White-browed Bulbul & Pycnonotus luteolus insulae \\
\hline Black Bulbul & Hypsipetes ganeesa humii \\
\hline Common Tailorbird & Orthotomus sutorius fernandonis \\
\hline Asian Paradise Flycatcher & Terpsiphone paradisi ceylonensis \\
\hline Black-naped Monarch & Hypothymis azurea ceylonensis \\
\hline Tawny-bellied Babbler & Dumetia hyperythra phillipsi \\
\hline Yellow-billed Babbler & Turdoides affinis taprobanus \\
\hline Yellow-eyed Babbler & Chrysomma sinense nasale \\
\hline Dark-fronted Babbler & Rhopocichla atriceps siccata \\
\hline Grey-breasted Prinia & Prinia hodgsonii pectoralis \\
\hline Common Mynah & Acridotheres tristis melanosternus \\
\hline White-rumped Shama & Copsychus malabaricus leggei \\
\hline Tickell's Blue-Flycatcher & Cyornis tickelliae jerdoni \\
\hline Thick-billed Flowerpecker & Dicaeum agile zeylonicum \\
\hline Pale-billed Flowerpecker & Dicaeum erythrorhynchos ceylonense \\
\hline Purple-rumped Sunbird & Leptocoma zeylonica zeylonica \\
\hline
\end{tabular}


Table 4: Density of commonly encountered endemic bird species.

\begin{tabular}{lll}
\hline Bird Species (Common Name) & Scientific name & Density $\left(\mathbf{h a}^{\mathbf{- 1}}\right)$ \\
\hline Yellow-fronted Barbet & Psilopogon flavifrons & 45.5 \\
\hline Crimson-fronted Barbet & Psilopogon rubricapillus & 10.9 \\
\hline Sri Lanka Scimitar Babbler & Pomatorhinus melanurus & 33.9 \\
\hline Sri Lanka Wood-Pigeon & Tephrodornis affinis & 39.2 \\
\hline Layard's Parakeet & Psittacula calthrapae & 11.9 \\
\hline
\end{tabular}

\section{DISCUSSION}

Endemism and the species richness are highly appropriate indicators for the prioritization of conservation exertions. Within a taxonomic assemblage, locally abundant species are usually tend to be more dispersed compared to rare species since rare species are restricted to a particular distribution (Kier et al., 2009). Therefore, some bird species, especially endemics, are restricted to certain areas. Thus, the conception of endemism is beneficial in quantifying the biological uniqueness of a particular area. Endemics are possibly the most sensitive species to habitat destruction and thus can be considered critical in indicating areas of special importance for conservation action (Linder, 1995).

According to the present study, Dunumadalawa Forest Reserve accounts for $41.6 \%$ of total endemism $(39.4 \%$ of endemic species and $42.7 \%$ of endemic subspecies) of the avifauna compared to the island endemics. A similar study done in Udawattakele Forest Reserve, which is also located within Kandy Municipal limits, found that it consisted of 51 species of birds belonging to 28 families (Weerakoon, 2015). This accounted for $21.2 \%$ of the country's avifaunal endemism. A study done in Ritigala Strict Natural Reserve in the northcentral dry zone has recorded 97 bird species out of which five endemic species (which means low endemism) (DWC, 2008). A more recent study conducted in Dekinda Forest, which is a hill rain forest enclosed by a municipal area in Balana has recorded 56 bird species with $34 \%$ of endemism (Wijesundara and Wijesundara, 2014). The percentage endemism in Dekinda forest is somewhat closer to the present study. Hence, compared to similar bird diversity studies conducted in different regions in Sri Lanka, the present study revealed that the Dunumadalawa Forest provides a favourable habitat for endemic bird species.

Almost all of the endemic bird species require well wooded areas for their existence (BirdLife International, 2008). The 'habitat heterogeneity hypothesis' suggests that forests with high structural complexity offer diverse microhabitats for foraging, nesting opportunities, and reduced predation (MacArthur and MacArthur, 1961; Lack, 1985). Differences in requirements among bird species have caused specificity on habitat requirements (Buckley and Freckleton, 2010). Since the Dunumadalawa Forest Reserve comprises of diverse habitats it supports a high avifaunal diversity. The preference of birds towards heavily forested undisturbed areas in Sri Lanka has been documented previously by de Zoysa and Raheem (1990). The Dunumadalawa Forest Reserve may serve as a refuge surrounded by highly urbanised human settlements. The reason for its high avifaunal diversity may partly be due to the fact that the interior of the forest as well as some of its borders (up to certain extent) have maintained almost undisturbed conditions.

Previous studies suggest that complexity of foliage pattern seems to be a better predictor of species diversity of birds than the diversity of tree species (MacArthur and MacArthur, 1961; MacArthur and Levins, 1964; Recher, 1969). According to the present study it was clearly evident that certain regions of the forest were dominated by certain species of birds. For example, Layard's parakeet (Psittacula calthrapae), and Sri Lanka Wood pigeon (Columba torringtoniae) were observed only in certain isolated areas consist of woody vegetation with low abundance of invasive plants and on very large tall trees. These species 
may prefer the remaining undistrubed parts of the forest because at present the forest composition has been relatively altered by alien plant species to a large extent. For example, Myroxylon basamum ('Yakada maran'/'Katta kumanjal') is outcompeting and overcrowding most of the habitats in the Dunumadalawa Forest Reserve. Besides that, there is a Pine (Pinus caribaea) plantation that spans over nearly 44 ha, and this has also resulted in altering the forest habitat. One central theme in biodiversity conservation applications is that to identify geographic concentrations of diversity and endemism (Gelderblom and Bronner, 1995). Therefore, identification of critical structural elements and their relationships to bird species richness and abundance is clearly important for the conservation of endemic species and forest management (Walters, 1991; Patton, 1992; Miller and Marion, 1995; Fischer and Lindenmayer, 2002).

In spite of being a secondary forest, Dunumadalawa is important in functioning as a habitat island for a significantly high floral and faunal diversity. The rate of loss of forests and wildlife habitats in Sri Lanka is considered as one of the highest in the South Asia (McNeely et al., 1990). Currently, Sri Lanka's old growth forests have been reduced to less than $20 \%$ of their pre-colonial extent due to ever-increasing human activities. As a result, some primary forests end up in being converted to secondary forests. Therefore at present, secondary forests make up an increasing percentage of forest cover in the island. However, these areas have a high conservational value as these emerging ecosystems in Sri Lanka can harbour substantial endemic and threatened faunas.

\section{CONCLUSIONS AND RECOMMENDATIONS}

Even though the Dunumadalawa forest is strictly protected preventing anthropogenic influences as much as possible, the alteration of the vegetation composition and the degradation of the habitat features are taking place unabated causing negatively on the fauna including birds encountering difficulties in their survival. Therefore, the most appealing way of addressing these issues are the implementaion of habitat conservation measures and enhancement. Improving existing habitats and creating new habitats without disturbing the natural ecosystem balance can be done by conducting a proper forest management program. Furthermore, under progressive forest management measures, maintenance and restoring of priority habitats and creating new habitats can be carried out to mitigate some of these issues. There is an ongoing program to remove Pinus plantation and re-plant the area with native species with the twin goals of improving water retentionand increasing the a vailable forest habitats for the wide array of species that live there (Kittle et al., 2014). Such projects can be helpful to conserve this Forest Reserve.

The present study has revealed that the Dunumadalawa forest harbours a relatively diverse avifauna with a substantial level of endemism. Thus gap evaluations to identify areas or species in need of further conservation is required. This is because establishment of protected areas alone may not be the only feasible means of conserving biodiversity. It becomes important to search for other, more practical solutions for protecting biodiversity through creating local conservation initiatives. The present findings highlight the importance of conserving this forest patch which is located in an urban area and therefore a proper conservation assessment is recommended to plan a more effective conservation program for this particular forest reserve.

\section{ACKNOWLEDGEMENTS}

We thank the Kandy Municipal Commissioner and the Officer-in-Charge of the catchment area, Mr. E.M.H.S.K Ekanayaka, for granting us permission to carry out this project in Dunumadalawa Forest Reserve, and the staff of the Forest Reserve for their guidance and assistance in the field. Support given by the Department of Zoology, University of Peradeniya, by providing equipment for this study, is greatly appreciated.

Tharangi Hettiarachchi would like to extend her thanks to those who helped in the field, Mr. and Mrs. Ekanayaka for their kind support throughout, and Dr. Gehan Jayasooriya of the Department of Botany, University of Peradeniya, for his help in identifying plant species. 


\section{REFERENCES}

Bibby, C., M. Jones, and S. Marsden. (1998). Expedition Field Techniques: Bird Surveys. Royal Geographical Society, London.

Bibby, C. J., N. D. Burgess, D. A. Hill, and S. H. Mustoe. (2000). Bird Census Techniques. 2nd edition. Academic Press, London.

BirdLife International. (2008). Important Bird Areas in Asia: Key Sites for Conservation. . BirdLife International, Cambridge.

BirdLife International. (2017). Endemic Bird Areas factsheet: Sri Lanka. Available from: http://www.birdlife.org. Accessed on: Aug 1, 2017.

Buckley, H. L., and R. P. Freckleton. (2010). Understanding the role of species dynamics in abundance-occupancy relationships. Journal of Ecology 98: 645-658.

Carey, A. B., J. Kershner, B. Biswell, and L. D. de Toledo. (1999). Ecological scale and forest development: squirrels, dietary fungi, and vascular plants in managed and unmanaged forests. Wildlife Monographs: 3-71.

Chan, S., M. J. Crosby, M. Z. Islam, and A. W. Tordoff. (2004). Important Bird Areas in Asia: Key Sites for Conservation. BirdLife International, Cambridge.

Colwell, R. K. (2013). EstimateS Version 9 User's Guide and Applications. Available from: http://purl.oclc.org/estimates. Accessed on: Sep 9 2015.

de Zoysa, N., and R. Raheem. (1990). Sinharaja: a Rainforest in Sri Lanka. March for Conservation, Colombo.

Dharmasena, C., H. Ekanayake, S. Abeysinghe, and N. Dharmasena. (2001). Dunumadalawa Forest Reserve. Loris 22: 55-57.

DWC. (2008). Biodiversity Baseline Survey: Ritigala Strict Natural Reserve. Department of Wildlife Conservation, Ministry of Environment and Natural Resources, Colombo.

Fischer, J., and D. B. Lindenmayer. (2002). Small patches can be valuable for biodiversity conservation: two case studies on birds in southeastern Australia. Biological Conservation 106: $129-136$.

Gelderblom, C., and G. Bronner. (1995). Patterns of distribution and protection status of the endemic mammals in South Africa. South African Journal of Zoology 30: 127-135.

Harrison, J. (2011). A field guide to the birds of Sri Lanka. 2 edition. Oxford University Press, Oxford.

Hortal, J., P. A. Borges, and C. Gaspar. (2006). Evaluating the performance of species richness estimators: sensitivity to sample grain size. Journal of Animal Ecology 75: 274-287.

Jones, J. A., M. R. Harris, and L. Siefferman. (2014). Physical habitat quality and interspecific competition interact to influence territory settlement and reproductive success in a cavity nesting bird. Frontiers in Ecology and Evolution 2: $1-8$.

Kier, G., H. Kreft, T. M. Lee, W. Jetz, P. L. Ibisch, C. Nowicki, J. Mutke, and W. Barthlott. (2009). A global assessment of endemism and species richness across island and mainland regions. Proceedings of the National Academy of Sciences 106: 9322-9327.

Kittle, A. M., A. C. Watson, P. Kumara, S. Sandanayake, H. Sanjeewani, and T. S. P. Fernando. (2014). Notes on the diet and habitat selection of the Sri Lankan Leopard Panthera pardus kotiya (Mammalia: Felidae) in the central highlands of Sri Lanka. Journal of Threatened Taxa 6: 6214-6221.

Kotagama, S., and A. Wijayasingha. (1998). Sirilaka Kurullo (in Sinhala). The Wildlife Heritage Trust of Sri Lanka, Colombo.

Lack, P. (1985). The ecology of the landbirds in Tsavo East National Park, Kenya. Scopus 9: 2-23.

Linder, H. (1995). Setting conservation priorities: the importance of endemism and phylogeny in the southern African orchid genus Herschelia. Conservation Biology 9: 585-595.

MacArthur, R., and R. Levins. (1964). Competition, habitat selection, and character displacement in a patchy environment. Proceedings of the National Academy of Sciences 51: 1207-1210.

MacArthur, R. H., and J. W. MacArthur. (1961). On Bird Species Diversity. Ecology 42: 594-598 CR - Copyright \&\#169; 1961 Ecological Soc.

McNeely, J. A., K. R. Miller, W. V. Reid, R. A. Mittermeier, and T. B. Werner. (1990). Conserving the world's biological diversity. IUCN, Gland.

Miller, S. H., and W. R. Marion. (1995). Natural and created snags and cavity-nesting birds in north Florida pine forests. Tallahassee.

Minitab, I. (2010). Minitab 16. Minitab Inc., State College, Pennsylvania.

Murcia, C. (1995). Edge effects in fragmented forests: implications for conservation. Trends in Ecology and Evolution 10: 58-62.

Nepstad, D. C., C. Uhl, and E. A. Serrao. (1991). Recuperation of a degraded Amazonian landscape: Forest recovery and agricultural restoration. Ambio (Sweden) 20: 248-255.

Patton, D. R. (1992). Wildlife Habitat Relationships in Forested Ecosystems. Timber Press, Portland, Oregon.

Ralph, C. J., J. R. Sauer, and S. Droege. (1995). Monitoring bird populations by point counts. Albany.

Ralph, C. J., and J. M. Scott. (1981). Estimating numbers of terrestrial birds. Cooper Ornithological Society, Lawrence, Kansas. 
Recher, H. F. (1969). Bird species diversity and habitat diversity in Australia and North America. The American Naturalist 103: 75-80.

Rice, J., R. D. Ohmart, and B. W. Anderson. (1983). Habitat selection attributes of an avian community: a discriminant analysis investigation. Ecological Monographs 53: 263-290.

Sutherland, W. J. (2006). Ecological Census Techniques: A Handbook. 2nd edition. Cambridge University Press, Cambridge.

Thomas, L., J. L. Laake, S. Strindberg, F. F. C. Marques, S. T. Buckland, D. L. Borchers, D. R. Anderson, K. P. Burnham, S. L. Hedley, J. H. Pollard, J. R. B. Bishop, and T. A. Marques. (2010). Distance 6.2. Research Unit for Wildlife Population Assessment, University of St. Andrews, UK.

Walters, M. (1991). Prosobonia ellisi, an extinct species of sandpiper from Moorea, Society Islands. Estratto Dal Bollettino Museo Regionalee Di Scienze Naturali 9: 217-226.
Warakagoda, D. (2007). The Bird Sounds of Sri Lanka: An Identification Guide (Audio CD). Drongo Nature Sound Library, Colombo.

Warakagoda, D., C. Inskipp, T. Inskipp, and R. Grimmett. (2012). Birds of Sri Lanka-Helm Field Guide. Christopher Helm, London.

Warakagoda, D., and U. Sirivardana. (2009). The avifauna of Sri Lanka: An overview of the current status. Taprobanica 01: 28-35.

Weerakoon, W. M. B. M. B. (2015). Avifaunal diversity of Udawattakele, an urban forest reserve in the Kandy District. Sciscitator 2: 19-21.

Wijesundara, C., and M. de Silva. (2005). Species diversity, abundance and some aspects of the ecology of birds in selected habitats in the hill region of Sri Lanka. Ceylon Journal of Science (Biological Sciences) 33: 15-31.

Wijesundara, C., and M. Wijesundara. (2014). Bird diversity of Dekinda Forest Reserve, Balana, Sri Lanka: Implications for conservation. Ceylon Journal of Science (Biological Sciences) 43: 137146. 